10. Shulzhenko D. I. Robota huvernera-psykhopedahoha z korektsii intelektualnykh ta autystychnykh porushen $\mathrm{u}$ ditei : Elektronnyi navchalno-metodychnyi posibnyk dlia studentiv Instytutu korektsiinoi pedahohiky ta psykholohii NPU imeni M. P. Drahomanova / D. I. Shulzhenko, O. V. Lisnichuk. 2005. $-250 \mathrm{~s}$.

11. Yalanska S. Systema proforiientatsiinoi roboty u navchalnomu zakladi / O. Yalanska // Psykholoh. - 2013. - № 11-12. S. 80-83.

12. Ostrovska K. O. Peculiarities of social competence in children with different autistic levels [Text] / K. O. Ostrovska // Journal of Education, Culture and Society. - 2013. - № 1. - P. 133-147.

Received October 11, 2017

Revised November 14, 2017

Accepted December 12, 2017

\title{
Shaping the desired behavior of children from alcoholic families as an aim of SUPPORT institutions and SOcial CARE
}

Paluch Marek. Shaping the desired behavior of children from alcoholic families as an aim of support institutions and social care / Marek Paluch // Problems of Modern Psychology : Collection of research papers of Kamianets-Podilskyi National Ivan Ohiienko University, G. S. Kostiuk Institute of Psychology of the National Academy of Educational Sciences of Ukraine / scientific editing by S. D. Maksymenko, L. A. Onufriieva. - Issue 39. - Kamianets-Podilskyi : Aksioma, 2018. - P. 220-231.

Marek Paluch. Shaping the desired behavior of children from alcoholic families as an aim of support institutions and social care. The article emphasizes that alcoholism is a disease. In contemporary social reality, more and more people are drinking alcohol which brings serious and often dramatic effects. Alcoholism is the cause of marginalization and social exclusion. Suffering generated from drinking of alcohol by one of the members of the family leads to social dysfunction of this family. A social worker plays an important role in preventive action and social interven- 
tion. Especially through education of the young generation, prevention efforts should be carried out, which in the future will prevent social problems associated with alcoholism. Only the competent procedures can minimize its effects. For this purpose, the whole society must be involved in the fight against addiction to alcohol and be responsible for the tragedies that take place in everyday life of polish citizens. Social work plays a very important role here, which aim is to help not only the alcoholic, but especially his family to come back to normal social functioning.

Key words: alcoholism, family, prevention, social intervention, support.

Марек Палюх. Формування бажаної поведінки дітей із сімей з алкогольною залежністю як мета підтримки установ соціального захисту. У статті наголошено, що алкоголізм - це хвороба. У сучасній соціальній реальності все більше і більше людей уживають алкоголь, що призводить до серйозних, часто драматичних наслідків. Алкоголізм є причиною маргіналізації та соціальної ізоляції. Страждання, спричинені вживанням алкоголю одним із членів сім’і, призводять до соціальної дисфункції цієї сім’ї. Соціальний працівник відіграє важливу роль у запобіжних діях та соціальному втручанні. Особливо шляхом навчання молодого покоління слід проводити профілактичні заходи, які в майбутньому запобігатимуть соціальним проблемам, пов'язаним з алкоголізмом. Тільки компетентні процедури можуть мінімізувати його наслідки. 3 цією метою все суспільство повинно бути залучене до боротьби з алкоголізмом та бути відповідальним за трагедії, що відбуваються у повсякденному житті польських громадян. Соціальна робота відіграє тут дуже важливу роль, мета якої - допомогти не лише людям з алкогольною залежністю, але й повернутись їхнім сім'ям до нормального соціального функціонування.

Ключові слова: алкоголізм, сім’я, профілактика, соціальне втручання, підтримка.

Formulation of the problem. Alcohol is still the most easily accessible psychoactive substance which very often makes young people drink it in large quantities, and this causes a number of problems, not only health but also social difficulties. Despite preventive measures most crimes are committed by people under the influence of alcohol. Alcohol is the cause of many tragedies in life, it is also the cause of marginalization and social exclusion. Drunkenness and alcoholism due to the negative impact on the unit (the man) has also negative social consequences: disintegration of the family, disruptive effect on the educational environment of children, neglecting work, unemployment, abnormal relations, crime [3, p. 41].

The aim of the article consists in the establishing measures providing support and assistance to an alcoholic family, and the means 
minimize the negative effects of exclusion and promote the proper functioning of social families.

The main material research. Drinking excessive amounts of alcohol in Poland is probably based on cultural background and centuries-old tradition. According to M. Jarosz, people drink in Poland in all environments: rural, small towns and big cities. However, drinking indicators rise during crises social and situational. Alcoholism and drunkenness also have negative and criminalize social impact. The alcoholics disintegrate their families, have a negative impact on family life [7, p. 247].

Any action against alcoholic or alcoholic families from social welfare institutions and social workers counteracts marginalization and social exclusion. All those institutions should impact an alcoholic in a way that he wants to accept the offered help and eventually decides to addiction treatment. The sufferings of the family go hand in hand with the alcoholism of a family member. There is poverty / unemployment / and what is more, the local environment evokes a sense of rejection, guilt, humiliation, loss of values. In order to counteract marginalization and exclusion a social worker must have a wide knowledge of the problems of addiction. The scope of this knowledge modifies the assessment of the situation, the interpretation of existing risks, and this affects the scope of the prevention objectives and social intervention [4].

«The family has its place among the other social institutions: economic, religious, political and law and together with them determines firmness of society", writes K. Frieske [5, p. 145]. Modern Family is exposed to many risks associated with social changes (economic and cultural), some of them are: separations and divorces, single-parent families, foster families and adoption, poor material and housing conditions of the family, domestic violence, alcoholic families, both or one of parents addiction to psychotropic drugs, etc. In such situations, child protection becomes very important. A child must be the primary entity of protective, preventive, educational and social services. The responsibilities of the family towards the child determine the legal system, especially family, welfare and educational law. The society has a keen interest in existence, forms and values of family life as well as how it shapes its members. According to Homplewicz, it is important to help the family in the form of effective "family policy». The family is the most effective institution of upbringing, although it does not have, according to the aforementioned author, any permanent plan and program of 
upbringing, because «...it educates through everything, constantly and continuously only due by the fact it exists». The family is considered as the prototype of social, environmental and also individual upbringing [6, p. 233-237]. Some projects in the field of social welfare and social work to the family include: identifying conditions in the community interview, diagnosis of the needs, help, counseling, support, benefits, social contract, crisis intervention and others. Social work is aimed, among other things, at helping families in offsetting existing deficits and meeting basic needs. To the important issues of the scope of assistance we can include the provisions of the Act of 9 June 2011 on family support and foster care system Journal [19].

Since 2012, families which have difficulty in fulfilling parental roles and parental care, may benefit from support of the family assistant. Assistant helps to overcome difficulties and facilitate the fulfillment of parents' social roles so that the family is able to work independently and correctly, and the family environment conducts the development and safety of children. The guarantor of this assistance is the law on family support and foster care which has been already cited. The assistant supports the family by searching for solutions to difficult situations with the help of family members, resources, extended family, community and aid institutions. The areas of family assistant activities include: caring, advisory, mediation, diagnosis, activating, monitoring, upbringing. At the same time they should take into account the psychological and emotional support as well as coordination between governmental, local government, relevant non-governmental organizations and other entities and individuals specializing in activities for child and family [19].

Social assistance is an activity for the benefit of human in need. The purpose of this is to implement changes in the sphere of living conditions (services, assistance in kind and provisions in the form of financial benefits). The most common situations in which the social assistance is provided are: alcoholism, homelessness, unemployment, disease, maternity, drug addiction, helplessness life, orphan hood, adaptation difficulties after leaving prison, poverty, developmental deficits (concerning the biological, psychological, social, cultural development [12, p. 91].

The family should create a natural, most beneficial environment for child development to shape his personality. As a social group, family is subjected to dynamic changes in its structure, implemented functions as well as its internal model. A family, in order 
to function properly, must meet many factors. The ones that cause problems and destabilize the family include: financial difficulties, poverty, unemployment, pathologies (alcoholism, drug addiction, violence, crime), which could lead to its dysfunctionality [20, p. 166].

Home and school are the main pillars of universal education, and with the growing importance of upbringing in society, they are the main areas of responsibility and interest of pedagogy. The modern family-oriented care system aims at providing support and assistance to a family before a dysfunction occurs. Support provided to the family in its environment is preceded by a diagnosis of social needs, because such families are usually large ones, broken, incomplete, unemployed, disadvantaged. The scope and forms of social help are determined by the Polish Act on social assistance. Those forms of state actions are accompanied by non-governmental forms of support for families such as preventive education, social compensation or rescue. Pedagogy supporting family the most often includes protection of the children rights, family legal assistance, development of parents' pedagogical culture and preparation for starting the family. Supporting the family and the child is first of all meeting the developmental needs of the child - reducing developmental deficits, enabling education, developing interests, preparation for life, attention to the relationship of the child with his parents. Support is, among others, provided by family, socialization, rehabilitation and intervention centers [16].

The family, which implements its functions properly creates conditions for individual development and meets the needs of its members. Dysfunctional family consists of dysfunctional people, who often through faulty educational system, generate pathological behavior. Dysfunction can mean the occurrence of failures in the implementation of family tasks and due to this fact the family has to be replaced by another institution or a person. In cases of only partial dysfunctions, difficulties may occur in only one function, e.g. an emotional, educational function. The child, in a dysfunctional family, is the weakest link. It lives in tension due to the unstable family situation, has unsatisfied needs- especially the need for love and security. This triggers a child's anger, fear, shame, which is reflected in its functioning in the environment. Support and versatile help for families at risk is needed to prevent the irreversibility of this dysfunction.

In recent years people addicted to alcohol receive a lot of help from social assistance. The Social Assistance Act of 12 March 2004 
[18] in art. 7 Section 13: «Social Assistance, on the terms specified in the Act, is granted to individuals and families, in particular due to ... alcoholism or drug addiction ... in municipalities», on the basis of art. 41 ust. 1 pkt. 2 of the Act of 26 October 1982 on Education in Sobriety and Counteracting Alcoholism (i.e. Dz. U of 2007 No. 70 , item 473 with later. Amendments), are created so called Municipal Commissions for Solving Alcohol Problems. The aforementioned Commissions are appointed in connection with the compulsory conduct of preventive measures and the area in which the problems with alcohol are solved. In addition, an important objective is the proper functioning of people addicted to alcohol and other drugs in society as well as activities related to the prevention of violence in the family environment. From the social work point of view (prevention), the most important consequence of the prolonged use of alcohol is alcohol addiction. "Modern science considers alcohol addiction as a bio-psycho-social disease which is distinctive from other diseases by the fact that almost every alcoholic has different symptoms - there are as many forms of the disease as many patients. This disease appears to be a reaction to the interaction of physiological, psychological and social factors» [8].

The number of people addicted to alcohol is growing at a rapid pace. All local aid institutions are required to counteract this threat. Now we are going to have a closer look at the activities of the Commission for Solving Alcohol Problems as these regional structures have the biggest problems in this regard. Tasks of GKRPATO are the following: taking action aimed at increasing the availability of therapeutic assistance and rehabilitation for addicts and co-addicts, including making analysis of needs in the area and managing the information and consultation points; providing psychosocial and legal support to the addicts and members of their families; providing preventive information and education in solving problems; taking measures regarding the availability of alcohol; cooperation with non-governmental institutions, organizations and individuals in solving the addiction problems.

Young people and children should be educated in the context of the addiction risks. Alcohol and drugs are the cause of life tragedies. Research conducted in the 90 s showed that in many families there is the disadvantage of care and upbringing, involving the lack of control by the parents over their children. There are the following problems: the lack of consistent upbringing activity, the collapse of the authority of parents, upbringing children in single-parent, 
deviant (pathological) families, bad economic situation (family socially excluded) and the risk of marginalization. Corncers are rised by the violations of the ban on the sale of alcohol to persons under 18 preventive actions on juvenile in accordance to the motto "prevention is better than cure» can be a contribution to the deceleration of demoralization and crime process. For the teaching and information purposes in this sketch, excerpts from publications of J. Miąsowicz "Police educational program of children, young people and their parents» will be used. It is an educational and preventive material submitted by the District Police Headquarters in Krosno - Prevention Department. In the chapters called «Parents' education» it is indicated that «educating parents on the subject of conditions of demoralization and crime among their children it has to be reckoned that this will be addressed at the same time to those who have a sense of parental duty, and those who understand the problem differently. Regardless of whether the subject will be carried out with a group of parents or individually, they should: realize that until the age of children's maturity, they are their legal representatives fully responsible for their actions; understand that there is a close link between the image of family functioning and child proceedings; avoid discrepancies between preachifyings and other proceedings (e.g. Saying that you must not steal, and fetching home other people's stuff); recognize the need for a subjective and non-objective treatment of their children, the partnership approach; learn how to talk to children about everything, eliminate taboos; have a basic knowledge about the pernicious effects of alcohol or drug use, know the reasons of using them by children and young people; find ways of avoiding risks and deploying them to children».

Moreover, the authors suggest that meetings with parents should inspire for discussion, and programs carried out among children and adolescents should teach children and youth how to behave on a daily basis, and realize the evil effects of using alcohol and drugs.

Sample topics of the classes with children and young people proposed by the authors of the program are: «The alien is a dangerous one»; "I can say NO»; "The phenomenon of demoralization and juvenile delinquency»; "Alcohol, drugs and other intoxicants». Such topics are tailored to the perception of children and adolescents [10].

The actions of social workers are focused on those in need and involve different areas of social problems, e.g. unemployment, poverty, protection of motherhood and large families, homelessness, 
orphanhood, disability, alcoholism, and drug abuse, difficulty in adjusting to life after leaving prison, long-term illness, helplessness in matters of care and education and running households, single-parent families or families with many children [17].

A social worker may carry out activities with an individual, group and community in the context of different levels of preventive interventions. Social work is primarily aimed at helping and improving the functioning of individuals, groups and communities, through actions aimed at their social relations. It should be emphasized that the prevention of social dysfunction is one of the main objectives of this activity. A social worker in the core tasks shall incorporate activities such as: concerning for the welfare of another person, expressed in the care of the needs of all people regardless of their socio-demographic, psycho-physical characteristics or social position; helping to solve problems arising as a result of the difficult life situations; responding to emerging social issues; planning of social changes; actions leading to the transformation of the environment, especially in the local community [14, p .142].

Education is a factor of human development and that is why, so-called intervention of an educational / upbringing character, directed on the environment, undertaken to stimulate, direct and support the transformation of the social order is so important [21]. Educational and socio-upbringing activities especially during the systemic change are of great importance for the whole society. Each educational activity that will reduce the phenomenon of borderline pathology is the success of all members of the community. Among the educational interactions, the so called inducing changes play an important role. In the literature this is often called an intervention in the individual (personal) or social (social group) system. Upbringing is a direct or indirect impact. Nowadays, educators pay great attention to the so-called «education towards values». This means that in the process of education a major role will be played by the value system with the hierarchy of values. Upbringing is important in the process of individual changes and social change. Upbringing activity has therefore always the nature of the double intervention [2, p. 234]. Cited author interprets educational interventions (education) aimed at the individual, as efforts to change their skills, attitudes, values.

Social work is oriented in not only aid but also educational actions. The whole educational system - family, school, vocational training is based on two remaining in the interplay of complementa- 
ry activities: the transfer of messages or skills, and socialization, or imprinting behavior consistent with those used in the society social norms. C. Robertis writes that educational activities tend in two directions: to the transfer of knowledge and skills, and socialization. The author distinguishes three types of objectives: transfer of knowledge and fostering learning behaviors associated with social roles fill-in by adults; develop the hidden abilities of children and youth by encouraging a variety of activities (cultural, sports, recreational); re-integration of young people into the social environment and adults, who broke social and legal norms [13]. Through educational activities in social work we can provide and develop pro-social attitudes based on allocentric values requiring treatment of another human being as an autonomous value, recommending the service of the good of others.

A social worker working in the community is dealing especially with the problems that must be resolved due to the social dimension, i.e. unemployment, poverty, homelessness, disabilities, old people, childcare, etc., and can use the following forms of action: social action, organization of the community, community development, education and promotion.

Social work has many different definitions (meanings), which combine some common elements, which M. Łuczyńska lists such as: the recipient of social work is the individual, the threatened left in a difficult situation family as well as the local community; the aim of social work is to improve the functioning of individuals, families and social groups, the end result is to bring them to life and selfdevelopment; the activity zone as well as the intervention of the relevant social work is the relationship between the individual and the environment [9, p. 92-93].

The aim of social work in this area will be providing assistance in meeting the needs and solving personal, family and social problems, on the proper functioning of society. An important task for the social worker will be working with various institutions in the community and the environment of educational and prevention institutions. Any relationship and impact of the social worker should serve startup assistance strategies and determining aid programs. Social work through its efforts, support, benefits, and crisis intervention can minimize the negative effects of exclusion and promote the proper functioning of social families. The family is the most important social group, since the future state of the nation depends 
on it and we should make every effort to foster its development and proper functioning [11].

Some projects in the field of social welfare and social work include: identifying conditions in the history of environmental, diagnosis of help needs, counseling, support, benefits, social contract, crisis intervention, and others. Social work is aimed among other things to help families in offsetting existing deficits and meeting basic needs. The important issues of the scope of assistance include the provisions of the Act of 9 June 2011 on family support and foster care system Journal [19]. Law cited above is based on the cooperation of many experts in the field of pedagogy, psychology, family law and practitioners working with children. This Act regulates the following issues: environmental prevention for families experiencing difficulties in carrying out its care and education functions, family foster care, institutional foster care, empowerment of adult foster care wards, adoption procedures, tasks of public administration in supporting family and foster care system.

The law has been created in the belief that effective help for families in difficulty in caring for and raising children and the effective protection of children «can be achieved through the cooperation of all persons, institutions and organizations working with children and their parents...», it also contributes to counteracting the marginalization and exclusion of families and their children [19].

Conclusion. In the social welfare and social work, we have to deal also with preventive actions, which are to minimize inappropriate behavior and restore the proper functioning of society. It is worth mentioning that the social worker and social assistance worker as a part of the educational work cooperates with all kinds of rehabilitation educational care institutions such as: daily support facility, intervention centers, family institutions, socialization centers, social reintegration centers [15].

Department of Social Welfare includes such assistance, which consists of: specialized family clinics; crisis intervention centers; support centers, educators, psychologists, consultants in social assistance centers, social workers; district family assistance centers; adoption and care centers; social clubs; youth social therapy centers; youth educational centers; children's homes, including homes for small children.

\section{References}

1. Reform Library № 40 Ministry of Education, On psychologicalpedagogical. - Warsaw, 2001. 
2. Brzezińska A. Psychology of education / A. Brzezińska // Psychology (ed. J. Strelau). - Gdańsk : Academic handbook, 2000. - P. 3.

3. Chlebio-Abed D. Primary prevention of alcohol addiction / D. Chlebio-Abed. - Katowice, 2000. - P. 41.

4. Chodkowska M. Pedagogy and the challenges of preventing marginalization and exclusion / M. Chodkowska, A. Mach (ed) // Pedagogy threats against the marginalization of individuals, groups and regions. - Rzeszow, 2011.

5. Frieske F. Care and control / F. Frieske, P. Poplawski. - Warsaw, 1996.

6. Homplewicz J. Pedagogy and ethics / J. Homplewicz. - Rzeszow, 2009.

7. Jarosz M. Social Pathology / M. Jarosz // Sociology in Poland. - Rzeszów, 1998.

8. Kulisiewicz T. Dependence alcohol syndrome // T. Kulisiewicz. - Warsaw, 1984.

9. Łuczyńska M. Social welfare institution / M. Łuczyńska, T. Kazimierczak (ed) // Introduction to Social Welfare. - Katowice, 1998.

10. Miąsowicz J. In the interests of minors and not only / J. Miąsowicz. - Krosno, 1998.

11. Paluch M. Social Pedagogy. The man in the system of socioeducational / M. Paluch, L. Chominska // Selected issues. Ukraine, 2012.

12. Radziewicz-Vinnytsia A. Social Pedagogy / A. Radziewicz-Vinnytsia. - Warsaw, 2008.

13. Robertis C. de. Methodology of action in social work / C. de Robertis. - Katowice, 1998.

14. Rybczyńska D. A. Axiology of social work / D. A. Rybczyńska, B. Olszak-Krzyżanowska // Selected issues. - Warsaw, 1995.

15. Regulation of the Minister of Labour and Social Policy of 26 September 2000.

16. Ordinance of the Ministry of Labour 19.10.2007.

17. The Act of 29 November 1990 on social assistance // Journal. Laws of 1998 № 64, item. 414, as amended. d.

18. Social Assistance Act of 12 March 2004 (Dz. U. of 2004 № 64, item. 593, as amended. Of Change) in art. 7 paragraph 13.

19. The law of 9 June 2011 on family support and foster care system and Acts. U. 2011 № 149, item. 887 Ministry of Labour and Social Policy Department of Family Welfare. 
20. Waltz W. Contemporary Polish family and its place in the system of ubringing and care / W. Waltz // Concepts of help to a man in theory and practice (ed Z. Frączek, B. Szluz). - Rzeszow, 2006.

21. Wiliński P. Place of educational intervention in the process of social change / P. Wiliński // Proceedings of the I National Conference. Education leaders in rural communities, 21-22.01.1997. - Poznań.

Received October 25, 2017

Revised November 24, 2017

Accepted December 19, 2017

\section{Розвиток ПСихологічної компетентності} КЕРіВНИКіВ НАВЧАЛЬНИХ ЗАКАААІВ ОСВіТИ 3 ПОПЕРЕАЖЕННЯ СИНАРОМУ «ПРОФЕСІЙНОГО ВИГОРАННЯ» ПЕААГОГіВ У ПісляАИПлОМніЙ ОСвіті

Pastukh L. V. The development of psychological competence of the heads of educational institutions on the teachers' "professional burnout» syndrome prevention in postgraduate education / L. V. Pastukh // Problems of Modern Psychology : Collection of research papers of Kamianets-Podilskyi National Ivan Ohiienko University, G. S. Kostiuk Institute of Psychology of the National Academy of Educational Sciences of Ukraine / scientific editing by S. D. Maksymenko, L. A. Onufriieva. - Issue 39. Kamianets-Podilskyi : Aksioma, 2018. - P. 231-243.

L. V. Pastukh. The development of psychological competence of the heads of educational institutions on the teachers' "professional burnout" syndrome prevention in postgraduate education. The urgency of the research on the development of psychological competence of the heads of educational institutions on the teachers' "professional burnout» syndrome prevention is actualized in the article. The analysis of researches and publications on the problem of professional burnout and psychological compe- 